Journal of Jazz Studies vol. 8, no. 1, pp. 93-99 (Spring 2012)

\title{
Pops Prevails
}

\author{
Edward Berger
}

What a Wonderful World: The Magic of Louis Armstrong's Later Years. By Ricky Riccardi. New York: Pantheon, 2011. 369 pp. \$28.95.

Louis Armstrong's later work is a far more controversial subject than one would expect, given his universal recognition as jazz's seminal creator and, at one time, arguably the world's most recognizable figure. But it is precisely his success in these two disparate and, to many, incompatible roles that led some critics to ignore his later artistic achievements and to bemoan what many viewed as his abandonment of his genius in pursuit of popular acceptance. Add to that the uneasiness engendered in some circles by Armstrong's complex stage persona, and the controversy becomes more understandable. Ricky Riccardi makes abundantly clear in this new and valuable work that, although Armstrong may have devoted his entire life to entertaining his audience, it did not preclude serious artistic achievement at all stages of his career.

Most writers, Riccardi included, use the transition from Armstrong's leadership of his big band to the formation of the All Stars in 1947 as the demarcation between early and late Armstrong. Since Armstrong recorded from 1923 to 1971, his "late" period spanned some 24 years—exactly half of his entire recording career. Moreover, some critics felt that Armstrong's contributions as a creative improviser ended even earlier, essentially dismissing much of his output after the Hot Fives and Hot Sevens. It is interesting to note how our concept of age has changed over the decades. For example, the celebrated tenor saxophonist Joe Lovano is 58 and considered to be at the peak of his game, while Armstrong was already being labeled an anachronism in his late forties.

A balanced assessment of Armstrong's later years was long overdue. Riccardi, however, is hardly a neutral observer. As the "magic" in the title suggests, the author's purpose is to redress the critical wrongs that he feels have been done to later Armstrong. The author's "agenda" is clear from the outset, although it is not explicitly stated until a summation at the very end of the last chapter: “...Armstrong's later years continue to be shrouded in myths. People still hurl the 'Uncle Tom' epithet. Hardened jazz fans focus on the Hot Fives

copyright by author $\$$ Except where otherwise noted, this work is licensed under 
and Sevens and ignore the All Stars. There are nonjazz fans who only know Armstrong through 'What a Wonderful World' and other coffeehouse pop songs that showcase yet another side of his genius, a more 'neutered' one. My hope is that in reading this book people from all musical backgrounds will finally begin to understand that the later years of Louis Armstrong's life were epic." He adds, "Although Armstrong was overwhelmingly popular throughout his career and died a national icon, his detractors have always had the loudest voices, which is why the negative view of his later years remains the standard after all these years" (305).

Riccardi is right. Many of jazz's most perceptive writers and astute listeners revealed a critical myopia and apparent tone deafness when confronted with Armstrong's later oeuvre. Unable to separate the trumpeter's image on stage from the music he was creating, they dismissed much of his 1950s and 1960s output seemingly without bothering to listen to it. Riccardi points out many of the most egregious critical transgressions in the jazz literature, beginning with Gunther Schuller's influential Early Jazz (1967) and The Swing Era (1987). In the latter, Schuller wrote that America should have provided Armstrong "with an honorary pension to live out his life in dignity, performing as and when he might, but without the need to scratch out a living as a good-natured buffoon, singing 'Blueberry Hill' and 'What a Wonderful World' night after night" (xiii). Or, as James Lincoln Collier wrote in his perverse Louis Armstrong: An American Genius (1983), "I cannot think of another American artist who so failed in his talent" (303). As has been noted elsewhere, ${ }^{1}$ in The Swing Era Schuller displays a peculiar and contradictory attitude toward artistic creation versus commercial success. He alternately chides bandleaders who forsook the former for the latter, yet condescendingly lectures others on their failure to achieve wider popularity. And neither he nor Collier seems to have much of a sense of humor-a prerequisite in any assessment of Louis Armstrong.

The popular press and jazz magazines seem to have presented a more favorable view of Armstrong, even as they fueled the largely manufactured moldy figs vs. bebop debates of the late 1940s. But Down Beat certainly ran pieces critical of Armstrong, one of the most vicious of which appeared in June of 1949 under the byline of critic D. Leon Wolff, who wrote, "The Armstrong myth is the most potent in jazz. This remarkable fable, which alleges that an unimaginative, halting trumpeter is the word's greatest, is practically

\footnotetext{
${ }^{1}$ See Morroe Berger, Edward Berger and James Patrick, Benny Carter: A Life in American $M u s i c, 2^{\text {nd }}$ ed. (Lanham, MD: Scarecrow Press, 2002), 429-430, and Lewis Porter, "Book Review: The Swing Era," Annual Review of Jazz Studies 5, 1991, 184.
} 
impossible to demolish." ${ }^{2}$ Wolff managed to savage both Armstrong and bebop as Orrin Keepnews noted in a rebuttal in which he decried the "motheaten old doctrine of dog-eat-dog in jazz criticism, the shrill and often meaningless cries that the other fellow's kind of jazz is a dirty fraud..."

Many writers were unable to come to grips with Armstrong's work because the trumpeter often displayed all aspects of his talent within a single performance. The audience-pleasing antics that so alienated the "serious" critics regularly coexisted with transcendent trumpet solos or vocals of great emotional depth and humanity. As the many surviving videos of Armstrong's performances from all eras show, when he put trumpet to lips the mugging and joking ceased and his demeanor became deadly serious.

Although, Riccardi rightly credits Dan Morgenstern as one of the writers who steadfastly defended Armstrong's later work, leading to something of a critical resurrection (abetted by Gary Giddins), Wynton Marsalis deserves more than the passing mention Riccardi accords him. The trumpeter's tireless proselytizing for Armstrong over the last three decades did much to increase his stature among younger musicians, students and the public worldwide. And Marsalis "discoveries" like Wycliffe Gordon have embraced the totality of Armstrong's contributions as both musical innovator and popular entertainer. Marsalis was undoubtedly influenced by Stanley Crouch, who is also barely mentioned. Unlike some African American writers, Crouch eschewed the simplistic "Armstrong as Uncle Tom" rhetoric and understood the complexity and nuance of Armstrong's character.

To a great extent, Riccardi allows Armstrong to speak for himself through the extensive use of quotes. He has done a superb job in incorporating well known sources such as the excellent 1966 Life interview with Richard Meryman, more obscure published material, as well as newly discovered audio interviews from the Louis Armstrong Collection at Queens College where Riccardi is an archivist. The picture that emerges is far more complex and layered than the crude stereotypes and embarrassing psychobabble which pervades some previous studies. There is much new material revealing Armstrong's self-awareness and introspection. For example, the trumpeter usually dismissed accusations of his supposed Uncle Tomming, his lack of commitment to the civil rights movement, and his allegedly moribund musical sensibilities by somewhat glib references to his ever -increasing popularity with the public. But Riccardi repeatedly demonstrates just how deeply these charges-particularly his abandonment by black audiences--affected

\footnotetext{
2 “Bop Nowhere, Armstrong Just a Myth, Says Wolff," Down Beat, June 17, 1949, 1.
}

3 "Changer' Editor Also Blasts Wolff," Down Beat, July 15, 1949, 12. 
Armstrong: "After he had been such a popular attraction to black audiences for years and years, by 1968 Armstrong's audience had become almost entirely white" (271). Riccardi cites a memoir written by Armstrong while he was recuperating at Beth Israel Hospital in 1969 and published in Louis Armstrong in His Own Words, edited by Thomas Brothers. Armstrong cannot contain his bitterness: "We were lazy and still are. We never did try to get together, and to show the younger Negroes such as myself to try and even to show that he has ambitions, and with just a little encouragement-I could have done something worthwhile." Quotes like this and many others from his last years reveal a side of Armstrong far removed from his ebullient stage persona--a side bordering on depression. On several occasions, he expressed his dissatisfaction with the grind of the road and hinted at retirement. Ossie Davis, who worked with Armstrong on the set of A Man Called Adam, described coming upon him in an unguarded moment and seeing "the saddest expression I've ever seen on a man's face" (246).

Trumpeter Joe Wilder, who met Armstrong in Philadelphia in 1936 when Wilder was fourteen, recalls seeing a similar side of the entertainer during a 1967 appearance on Kraft Music Hall television program. Wilder, who played in the show's orchestra, remembers that during an interview segment "Louis became very serious and said, "Everyone thinks that Pops is a "Tom," but in those days you could be lynched if you didn't play the game-you didn't know if you would live or die.' He looked so sad that I had tears in my eyes hearing him tell about it."

Riccardi confronts the charges that Armstrong was not sufficiently involved in the struggle for civil rights by reviewing his well-known explosion over the Little Rock school integration incident, as well as documenting the many other occasions on which the trumpeter took a stand. The free-thinking Lester Bowie provided perhaps the clearest insight into Armstrong's strategy in battling racism: "The true revolutionary is one that's not apparent...I mean the revolutionary that's waving a gun out in the streets is never effective; the police just arrest him. But the police don't ever know about the guy that smiles and drops a little poison in their coffee. Well, Louis, in that sense, was that sort of revolutionary, a true revolutionary" (xvi).

A recurrent theme in Riccardi's refutation of Armstrong's purported sellout to commercialism is the fact that he had always played "popular" music throughout his career, including during the early period universally lauded by the critics. He makes a convincing case, tracing the variety of musical influences that shaped Armstrong's style - from his early exposure to opera, to

${ }^{4}$ Unpublished interview with Ed Berger, March 2007. 
the dance music that constituted a significant portion of his repertoire with Fletcher Henderson, and his masterful transformations of popular songs like "Star Dust," "Georgia on My Mind," "Body and Soul," and "I Got Rhythm" from the early 1930s. "Thus, for critics to start attacking Armstrong for recording 'commercial' music in the fifties and sixties shows just how ignorant those writers were about Armstrong's entire career. From the day he was born until the day he died, Louis Armstrong performed-and listened to-all kinds of music. Thus, by the late sixties, when Armstrong was recording songs like the Lovin' Spoonful's 'Daydream' and John Lennon's 'Give Peace a Chance,' he was just recording the popular songs of the day, something he had really never stopped doing since he first picked up a horn in New Orleans" (49-50). Riccardi also cites some evidence that Armstrong was worried about becoming stagnant artistically. After his return from a triumphant European tour in 1950, the trumpeter told Holiday magazine that he could never settle there permanently because "the musical times be slipping by you and then when you realize it—sure 'nuff-you'll find you're ten years behind the time" (47).

Riccardi also sheds new light on the complicated relationship between Armstrong and his longtime manager Joe Glaser through newly discovered materials at the Louis Armstrong House Museum. While Armstrong and others credited the often boorish Glaser with stabilizing the trumpeter's financial situation and making him a star, the manager has also been accused of controlling him with a near plantation-style paternalism, working him to death, and repeatedly thwarting opportunities to expand his musical horizons. While there is truth in both these interpretations, Riccardi presents new and compelling evidence that it was Armstrong himself who ultimately called the shots. Similarly, there is much new information about the changing dynamics and interrelationships within the various editions of the All Stars, beginning with an analysis of the friction between Armstrong and Earl Hines. He points out the failings of individual members as well as entire units over the years (clarinetist Barney Bigard, for example, fares particularly badly).

In his quest to resurrect Armstrong's later years from critical oblivion, Riccardi can be overzealous and repetitious at times. His detailed documentation of Armstrong's grueling schedule, the ups and downs of his battered embouchure, his constant references to the trumpeter's well-known obsession with the laxative Swiss Kriss and other idiosyncrasies can occasionally have a numbing effect. To refute the charge that Armstrong played the same material night after night and year after year, Riccardi goes to great lengths to show the variety that existed both in the repertoire and interpretation of the All Stars. He overstates the case, for anyone who has perused an Armstrong discography or listened to a sampling of the many 
available live recordings will find that the group did essentially repeat the same program, with notable exceptions of course. On this score, Riccardi is needlessly defensive, as almost every touring group in any jazz style routinely repeated its program and few delivered it with Armstrong's sincerity and enthusiasm. When clarinetist Edmond Hall left the band in 1958, he gave as a reason, "With Louis we played the same concert night after night without any variety...A guy's got to do something new once in a while to develop" (177). Riccardi, who earlier acknowledged that Hall's "uniquely dirty tone was a godsend to the group's front line" (110) and that after he joined "the All Stars never sounded better" (111), now dismisses the clarinetist's criticism out of hand: "Hall used the hackneyed critique of the band's repertory as an excuse to leave" (177).

Riccardi may also overstate the criticism leveled at Armstrong from his fellow musicians. Even during the trumpeter's lifetime the pendulum may have begun to swing back in his favor as evidenced by Down Beat's issue marking Armstrong's $70^{\text {th }}$ birthday, which contained encomiums from 86 musicians from all points on the musical spectrum. ${ }^{5}$ And while there is no denying that Armstrong's audiences in later years were predominantly white, the notion that the black community had forsaken him is also misleading. The African American press covered Armstrong extensively and in a positive light during the 1950s and 1960s. Articles appeared regularly expressing pride in the trumpeter's roles in major films, his overseas triumphs, and his appearances on behalf of various charities and educational and civil rights organizations. Finally, as one of the thousands who filed by his casket at the Seventh Regiment Armory in New York on July 8, 1971, I can attest to the fact that many African Americans of all ages and from all walks of life came to pay their last respects.

One of the book's strengths is the author's survey--integrated within the narrative--of Armstrong's recordings of the 1950s and 1960s. A pianist himself, Riccardi identifies exceptional performances and moments of particular interest within those performances without getting overly technical. Recordings such as Louis Armstrong Plays W.C. Handy, Satch Plays Fats, the collaborations with Ella Fitzgerald, Oscar Peterson, Duke Ellington, and the Dukes of Dixieland, The Real Ambassadors with Dave Brubeck, and the many exciting live recordings of the All Stars worldwide provide incontrovertible evidence of Armstrong's continued creativity in his "later" years. Perhaps nowhere was this more evident than in his 1956 Autobiography project for Decca, on which the trumpeter revisited some of the earlier material on which

5 “Roses for Satchmo," Down Beat, July 9, 1970, 15-19. 
his reputation as a jazz innovator was based. As Riccardi rightly points out, in many instances Armstrong's playing surpassed the originals in both technique and feeling. In many cases Riccardi provides valuable background information. For example, access to the session tapes and interviews with producer George Avakian enabled Riccardi to trace in detail the genesis and evolution of Armstrong's short but significant tenure with Columbia in the mid-1950s, which yielded the landmark Louis Armstrong Plays W.C. Handy. In addition to enhancing our appreciation of well-known, latter-day classics, Riccardi also calls our attention to less auspicious but nevertheless rewarding recordings like Disney Songs the Satchmo Way (first praised by Giddins), and some lesserknown gems in the Armstrong discography.

Despite his admittedly pro-Armstrong bent, Riccardi is able to maintain some objectivity in his critical assessment of the recordings, though, at times, he gets a bit carried away in his enthusiasm. A typical instance occurs in his discussion of The Real Ambassadors, Armstrong's felicitous collaboration with Dave and Iola Brubeck. He describes a rather straightforward 16-bar trumpet melody statement on "You Swing Baby" (a.k.a.The Duke) as "stunning."

Hyperbole aside, Riccardi's work is a major addition to the Armstrong literature and provides new insight into an often neglected and frequently maligned period in the career of an American icon. It is vindication for those who always admired the trumpeter's later work and a valuable introduction to those exploring the glories of latter-day Armstrong for the first time.

\section{ABOUT THE CONTRIBUTOR}

ED BERGER recently retired after three decades at the Institute of Jazz Studies (IJS) to pursue freelance writing and photography. He is a regular contributor to JazzTimes as both writer and photographer, and author or coauthor of three works in the Scarecrow Press/IJS Studies in Jazz series: Benny Carter: A Life in American Music; Bassically Speaking: An Oral History of George Duvivier, and Reminiscing in Tempo: The Life and Times of a Jazz Hustler, the memoirs of producer Teddy Reig. His photographs have appeared in many periodicals as well as on recordings by such artists as Benny Carter, Phil Woods, Frank Wess, Quincy Jones, and Ray Bryant. He is currently working on a biodiscography of trumpeter Joe Wilder. 